\title{
Thin- and thick-skinned salt tectonics in the Netherlands; a quantitative approach
}

\author{
J.H. ten Veen ${ }^{*}$, S.F. van Gessel \& M. den Dulk \\ TN0 - Geological Survey of the Netherlands, P.0. Box 80015, 3508 TA Utrecht, the Netherlands. \\ * Corresponding author: johan.tenveen@tno.nl.
}

Manuscript received: December 2011, accepted: July 2012

\begin{abstract}
The Zechstein salt in the Dutch part of the North Sea Basin played a key role in the generation of successful petroleum plays. This is not only because of its sealing capacity, but also because the salt occurs in structures that provide lateral and vertical traps. The structural styles of areas with thick salt and those with none- or thin salt are completely different during phases of extensional or compressional tectonics. This indicates that, indirectly, the depositional thickness of the main Zechstein salt is essential in regulating the loci of the Dutch petroleum systems. In this paper we aim at quantifying current ideas on the relationship between 1) depositional salt thicknesses; 2) structural style of the main structural elements identified in the Dutch subsurface; 3 ) timing of deformation; and 4) thickness of the overburden. By finalisation of TN0's subsurface mapping program (see Kombrink et al., this issue), several data products are available that allow evaluation of these relationships. The depositional thickness of the salt was estimated using iterative smoothing of the present day thickness, the results of which account both for regional thickness variations and volume preservation (99\%). Fault-distribution analysis shows that faults are only able to penetrate salt with a depositional thickness of $<300 \mathrm{~m}$, a transition that demarcates the division between thin- and thick-skinned salt tectonics. In the southern offshore where the salt is thin or absent, the overburden shows the same fault pattern throughout the stratigraphic sequence. In the northern realm, where salt is thicker than $300 \mathrm{~m}$, the salt layer acted as decollement and sub- and supra salt strain are dissimilar. A strong genetic and temporal relationship exists between periods of regional tectonism, halokinetic intensity and thickness distribution of the Zechstein overburden. This relationship is further proven by burial history analysis across two selected profiles in the northern offshore. The analysis focuses on the vertical distribution of the salt by taking into account the depositional and erosional history of the salt overburden, without a-priori defined periods of salt flow. The results corroborate the notion that platforms and highs experienced less extension during the major phases of Jurassic rifting and further suggest that the absence of a thick Jurassic overburden precludes major salt flow during this tectonic phase. Main salt flow was triggered during the SubHercynian and later phases of compression resulting in salt pillow geometries. In the basinal areas, where the Jurassic succession is thickest, salt diapirs and walls formed that are almost exclusively linked to major subsalt faults. Main salt flow occurred during Late Kimmerian rifting, whereas some minor structuration occurred during Sub-Hercynian inversion.
\end{abstract}

Keywords: Zechstein, North Sea Basin, halokinesis, structural evolution, burial history analysis

\section{Introduction}

In Northwestern Europe, most hydrocarbon discoveries and successful plays in the Mesozoic and late Paleozoic sequence are located in structural traps that have formed in response to salt tectonics (Remmelts, 1996; De Jager, 2003). Either the traps are formed adjacent to salt structures, are fault-bounded, or a combination of both. Rotliegend reservoirs form the largest
Dutch natural gas occurrences, located in structural traps that consist of tilt-block geometries commonly sealed by Zechstein salt. Thus, sub- and supra salt faults and salt structures play an essential role in the formation of successful plays. An improved understanding of the delicate interplay between salt and faults forms the fundamental basis for future successful exploration. Over the last 50 years the ideas on triggering mechanism(s), timing and modes of salt structure formation (halokinesis) have 
changed. One of the oldest ideas is that salt penetrates the overburden sediments (salt piercement model of Trusheim, 1960) due to differential loading. This view neglects the currently acknowledged role of active faulting in creating the lateral differences in sediment loading (e.g. Vendeville \& Jackson, 1992; Vendeville, 2002). The arrival of 3D seismic data and improvement of seismic analysing techniques and -software enabled a better seismic and structural interpretation that changed the interpretation of salt diapirs from buoyancy-driven piercing structures into phenomena associated with the main extensional grabens in NW Europe (e.g. Mohr et al., 2005).

As pointed out by Geluk (2007), it is extremely important to differentiate between areas with thick salt and those without salt (Fig. 1), since the structural styles of these areas are completely different during phases of extensional or compressional tectonics (De Jager, 2007). Several models and views exist on

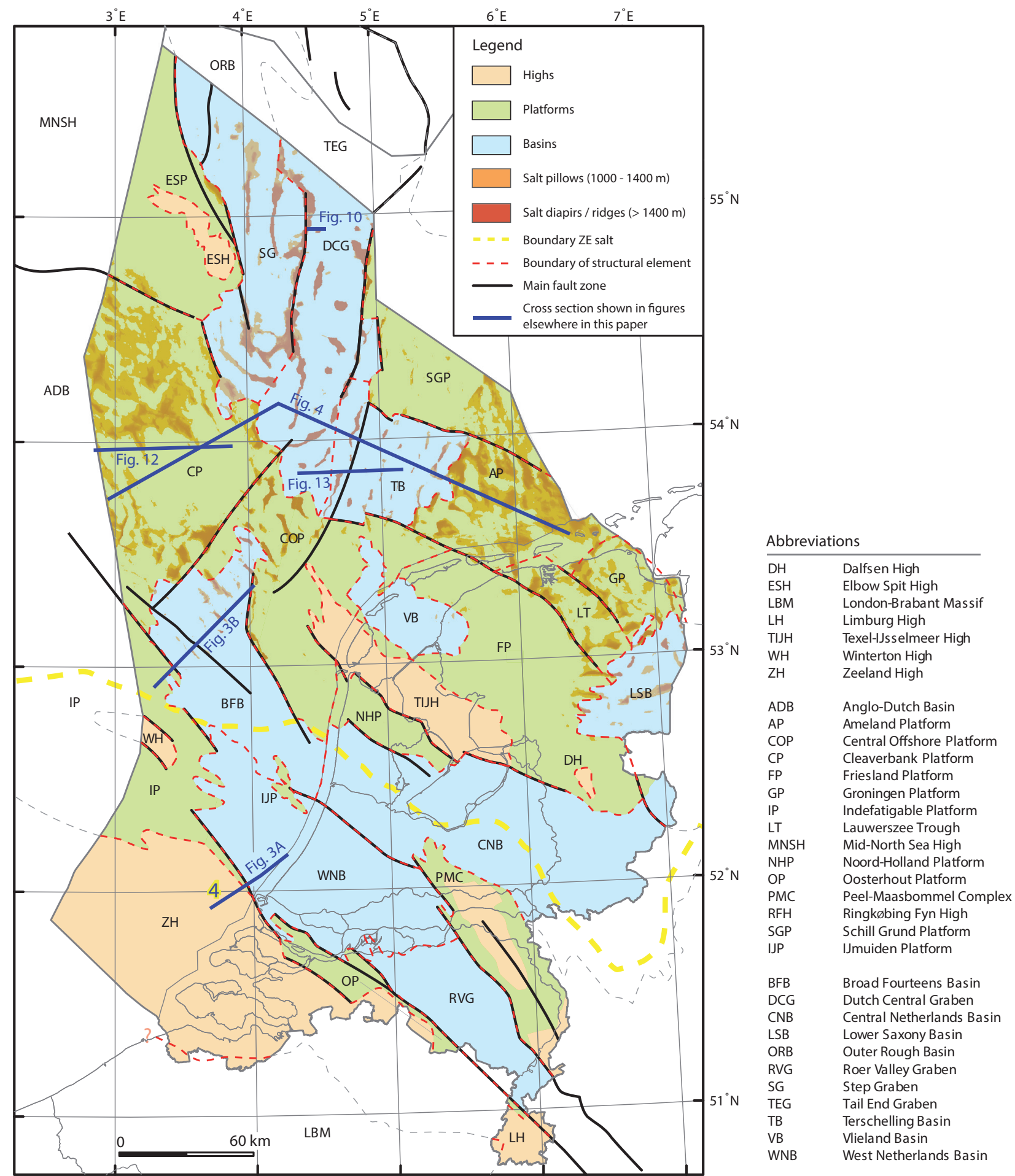

Fig. 1. Main structural elements and salt structures in the Dutch realm of the North Sea Basin (modified from Kombrink et al., this issue). 
where the main deformation (strain) is accommodated in sedimentary basins that contain packages of (mobile) salt. If the original burial depth exceeds $\sim 1000-1500 \mathrm{~m}$ (10-15 MPa), salt starts to deform plastically (Jackson \& Talbot, 1991), which is the case for most of the ZE salt occurrences in the Dutch subsurface. Furthermore, the thickness of the salt layer(s) is crucial in driving the type of deformation, i.e. thick- or thinskinned, and controls the structural development of a sedimentary basin. Where deformation (including faulting) of the salt cover is directly linked to basement faults, the term thick-skinned is commonly used, while the term thin-skinned refers to structural settings where the salt detaches its cover from the basement and basement faults (Vendeville \& Jackson, 1992; Stewart et al., 1996). If salt thickness within a basin changes laterally, both types may exist next to each other (Scheck et al., 2003a). Assuming that halokinesis can diminish the original salt thickness, thin-skinned fault systems may evolve into thick-skinned settings through linkage of sub- and supra salt faults.

Earlier studies (e.g. Remmelts, 1996; De Jager, 2003) already suggested a close relationship between 1) depositional salt thicknesses; 2) structural style of the main structural elements identified in the Dutch subsurface; 3 ) timing of deformation; and 4) thickness of the overburden. In this paper, we use all available to data to further elaborate on these controls in a quantitative manner, partly because the recently finished mapping project (see Kombrink et al., this issue) provided a regional structural model which was not available before. This model is based on an enormous new dataset that allows to present a detailed- and quantitative overview of salt-related structural phenomena in the Netherlands. The approach presented here will lead to better understanding the temporal and areal distribution of salt structuration and may be of help in hydrocarbon exploration.

\section{Relationship between faults and salt structures}

When one or more salt layers are present during extensional tectonics, a characteristic set of structures are formed. Normally, extensional faults propagate up from the middle part of the crust until they encounter the salt layer. The ductile behaviour of the salt prevents the fault from propagating through. However, continuing displacement on the fault deforms the base of the salt and causes flexural bending of the overburden layer (Figs 1 and 2). Eventually, the stresses caused by this bending will be sufficient to fault the overburden. The types of faults are clearly related to the thickness of the (now) structured salt (fault type 3B in Fig. 2). In case of a very thick salt layer there is no direct spatial relationship between faulting beneath the salt and in the overburden. Such a system is said to be unlinked (Stewart, 2007) or thin-skinned. However, due to crestal collapse of a salt diapir, ridge collapses due to dissolution or differential compaction above the salt structure, small extensional faults may develop that are commonly arranged in a radial pattern (Stewart, 2007). For intermediate salt thicknesses, the overburden faults are spatially related to the deeper faults but show a lateral offset, normally into the footwall. This structural style is known as a soft-linked system.

In a thick-skinned setting, where the salt layer is (or becomes) thin enough, the fault that develops in the overburden is closely aligned with that beneath the salt which, after only a relatively small amount of displacement, may merge into a continuous or so-called hard-linked fault (Stewart, 2007). Potentially, thin-skinned systems can evolve into thickskinned systems by reactivation of previously-unlinked faults above and below the salt layers. In salt welds, where salt is almost or completely removed, the fault may eventually penetrate the whole rock sequence. Both soft- and hard-linked fault systems form in thick-skinned settings, because cover deformation and diapir location are directly linked to basement faults (Fig. 2). Thus, the depositional salt thickness is crucial in determining the potential of faults to propagate upward. During continuous salt flow and thinning of the salt, this potential may increase.

In thin-skinned settings, so-called salt rollers (Bally et al., 1981) or pillows describe low-amplitude deflections of the upper surface of a salt layer at the lower termination of normal faults in the overlying sediments. For the Dutch subsurface, these structures are defined by salt thicknesses between 1000-1400 m (Fig. 1). Intensive seismic exploration in sedimentary basins worldwide has demonstrated their occurrence in two forms: (i) below tilted fault blocks or (ii) on synthetic or antithetic growth fault/rollover systems (Brun \& Mauduit, 2009). The latter case describes either deposition of evaporites within the syn-rift

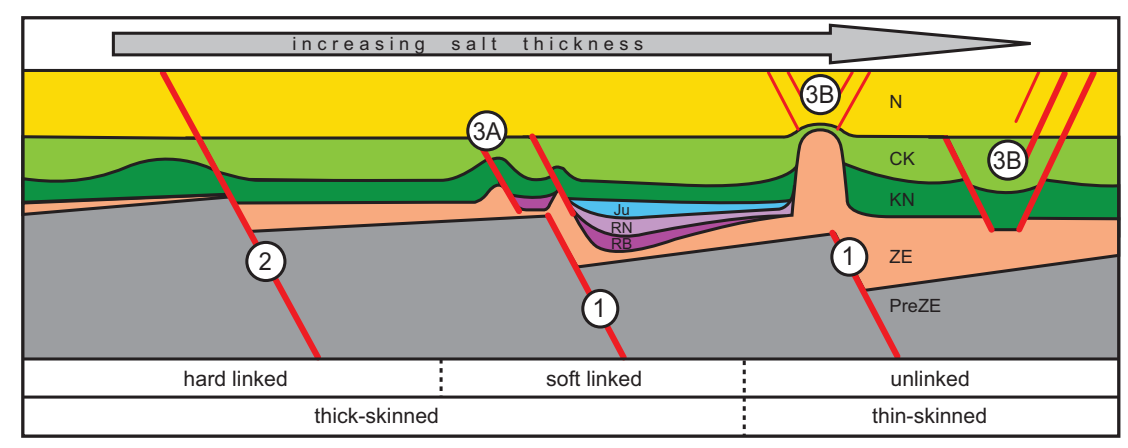

Fig. 2. Cartoon modified from Stewart (2007) and adapted to the Dutch North Sea, showing a general $\mathrm{N}$-S section. From left to right salt structure height and original salt thickness increase. Fault types as listed in Table 1. 
package of an extensional system (Vendeville \& Cobbold, 1987), or post-depositional fault (re)activation below the salt layer. Both scenarios have been described from the Dutch subsurface. For instance, Geluk (2007) describes syn-rift salt fill of Permian tilt-block basins that formed during the Tubantian extensional phase, which is seen as a relaxation phase of the Variscan orogeny. Also later fault-block tilting can cause salt flow due to differential loading related to thickness variations in the salt's overburden. This is, for instance, exemplified by the so-called Triassic Fat Sands that occur as isolated wedges in rim synclines associated with early salt tectonics (De Jager, this issue). These wedges confirm that the first salt movements took place during the Early Triassic (Dronkert et al., 1989). Early salt movements favored the preservation of aeolian sand in the shadow zone of salt-dome related morphological highs (see De Jager, this issue).

No matter whether extension occurs after or during salt deposition, it is evident that salt becomes progressively and differentially buried with continued extension. The mobile salt fills the space created in the tensional regime, forms into rollovers and will tend to migrate up into normal faults (the reactive phase of Vendeville \& Jackson, 1992; Jackson \& Vendeville, 1994). This phase sets the stage for rim syncline formation and continued uneven distribution of sediment infill and loading. If extension continues, salt flows more actively and enhances the differential loading which in turn affects the salt flow. This 'perpetuum mobile' mechanism is referred to as the active phase (Vendeville \& Jackson, 1992), which will stop as soon as the differential loading is levelled, for instance when active extension ceases. Different generations of rim syncline development may thus point to periods of enhanced salt flow, and are valuable for interpretation of changes in the orientation and intensity of the regional stress field. During the active phase (Vendeville \& Jackson, 1992) the salt may rise towards the surface and form diapirs (thickness $>1400 \mathrm{~m}$ ). Subsequently, during the passive phase, the salt maintains its near-surface position by keeping pace with the rate of sedimentation (assuming sufficient salt is available).

This (de)formation scenario also forms the basis for a $3 \mathrm{D}$ backstripping approach that considers salt flow in the North German Basin to result from spatially changing overburden load distribution, isostatic rebound and sedimentary compaction (Scheck et al., 2003a, b; Hansen et al., 2007). This method allows determination of the amount of vertical tectonic movements and quantification of the related active salt movement as a consequence of temporal changes of the regional stress field (Scheck et al., 2003b). Similarly, distinct phases of salt tectonics were deduced from retrodeformation of salt structures in the Central European Basin (Mohr et al., 2005).

In thick-skinned settings, either salt is absent or the role of the salt layers is far less important in determining location and propagation potential of faults. Therefore, salt structures are virtually absent and the salt-bearing sequence is displaced by continuous basement faults. These are either pre-existing and reactivated- or are newly formed during post Zechstein deformation. In thick-skinned settings the sequence of rocks affected by the fault can be used to determine the relative age of faulting. In thin-skinned settings this is more difficult, due to the decoupling effect of the highly ductile salt layers.

\section{Salt thickness in the Netherlands}

\section{Geological setting}

The TNO 3D structural model (Kombrink et al., this issue) contains thickness information of all stratigraphic units from Rotliegend to Cenozoic times. In general, the Zechstein Group is stratigraphically constrained between the Coppershale Member (Kupferschiefer) at the base and the Zechstein Upper Claystone Fm. at the top. The base and top of the Zechstein Group both appear as high amplitude, regional consistent reflectors in seismic data. The thickness of the Zechstein Group increases from less than $50 \mathrm{~m}$ in the southern part of the Netherlands to more than $1200 \mathrm{~m}$ in the northern offshore (Geluk, 2007). Locally, in salt diapirs and ridges, thicknesses exceed $8 \mathrm{~km}$.

The structural model does not include regional information on the internal stratification of the ZE Group, but several facies distribution maps based on numerous lithostratigraphic well-log interpretations (e.g. Geluk, 2000, 2007) and a limited number of local seismic studies (e.g. Van Gent et al., 2010) reveal more detail. The sediments of the Zechstein Group occur in repetitive cycles (Z1-Z5 in the Netherlands), which are controlled by the interplay of transgressions from the Arctic and evaporation of seawater in the arid Southern Permian Basin (Taylor, 1998; Peryt et al., 2010). The Z1-Z3 cycles are marine in nature and comprise a typical evaporation sequence with, from bottom to top, clay(stone) - carbonate - gypsum (anhydrite) halite - potassium and magnesium salts. Lateral facies changes indicate the overall northward deepening configuration of the Zechstein basin. Generally, during carbonate deposition of the Z1-Z3 cycles a typical platform-slope-basin configuration existed, whereas during the subsequent evaporation phase (Z4Z5) mudflats and sabkhas dominated the southern basin fringe and evaporites the deeper parts of the basin to the north (Geluk et al., 2007). The thickest halite layers occur in the Z2 cycle (Strassfurt Halite Mb.) and Z3 cycle (Leine Halite Mb.) and reach thicknesses of up to $600 \mathrm{~m}$ and $300 \mathrm{~m}$, respectively. The Z2 salt has the highest percentage of halite (>95\%) and forms the most important top seal for the Upper Rotliegend gas reservoirs (Geluk, 2007) and is the main diapiric salt. In the southernmost part of the Netherlands the Z2 and Z3 salts are absent (Fig. 3a). The Z4 en Z5 cycles are deposited in a playa setting and comprise basal claystones and thin anhydrite or salt layers higher up in the sequence; carbonates are lacking. The Zechstein upper Claystone Formation is a regionally extensive clay succession deposited in a lacustrine to mudflat setting (Van Adrichem Boogeart \& Kouwe, 1993; Geluk, 2007). 

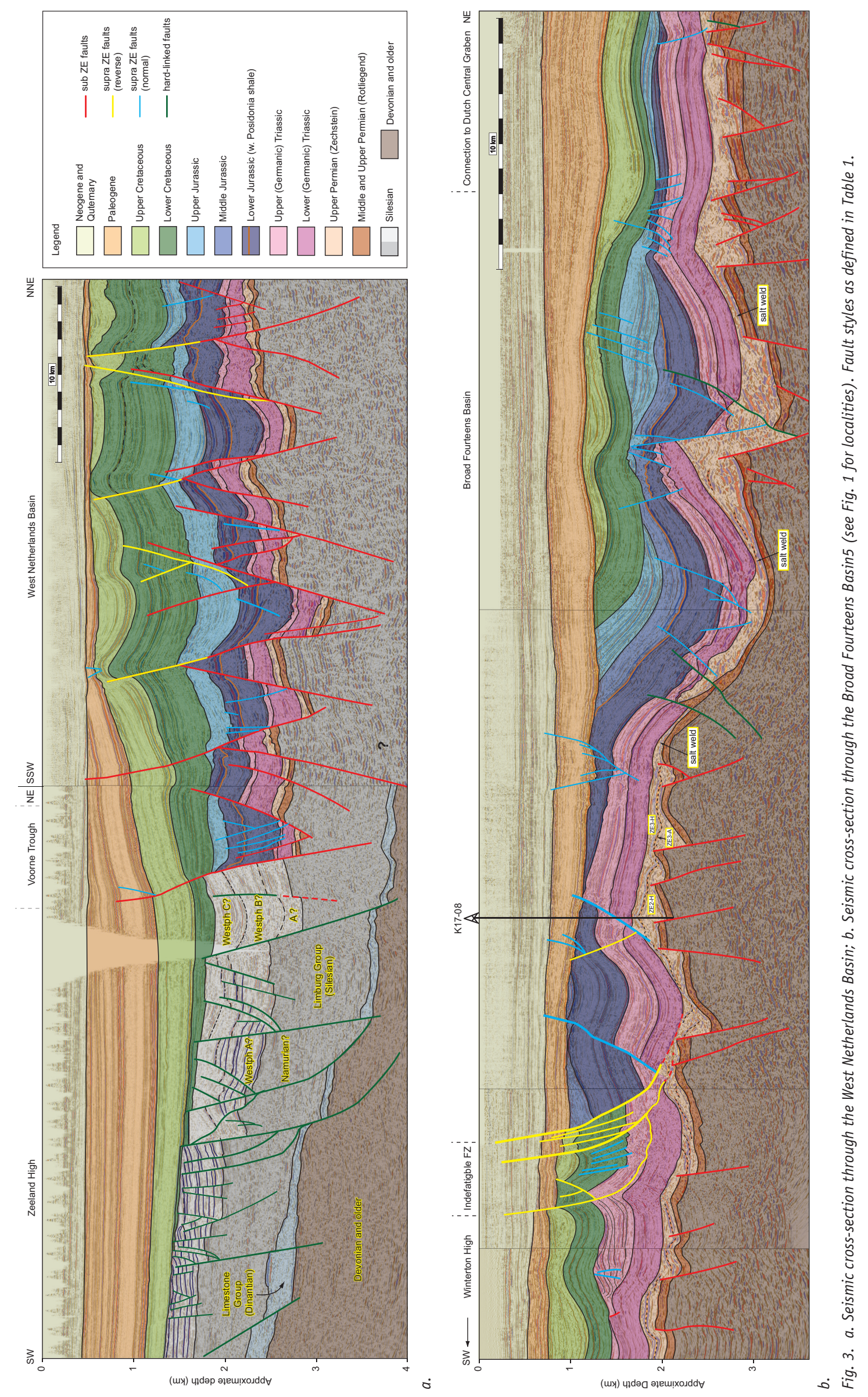

Netherlands Journal of Geosciences - Geologie en Mijnbouw | 91 - 4 | 2012 
In the northern part of the Netherlands and in Germany, evaporitic layers also occur interbedded in the stratigraphically lower Upper Permian Rotliegend Group (Silverpit Evaporite Member), with thicknesses up to $50 \mathrm{~m}$ (Geluk, 2007). Locally, these layers have been mobilised into salt pillows and in Germany even into diapirs.

\section{Salt thickness and mechanical behaviour}

Since it is the thickness and presence of mechanically ductile salt that plays a key role in halokinesis and the post Permian structuration of the Netherlands, the salts should somehow be separated from the remainder of the ZE group in order to quantify their role. Subtraction of the thickness of non-salt lithologies from the ZE-group thickness, based on well-log information is one possible approach, but this neglects the possibility that thin or interbedded salt layers (in carbonate or anhydrite) may show brittle behaviour. For instance, the Z1 (Werra Fm.) Salt Member has a very limited extent and its thickness does not exceed $\sim 50 \mathrm{~m}$ (Geluk, 2007). Although the limited thickness impedes a good identification of this salt member in seismic data, in the Broad Fourteens Basin (Fig. 3b), it can be clearly seen that several of the basement faults transect the Zechstein sequence below the thick Z2 salts. These faults terminate at the base of the ductile $\mathrm{Z2}$ salt but cut the Z2 Main dolomite and Z2 Basal Anhydrite Member that directly overlie the Z1 anhydrite. Therefore, all rocks up to the top of the Z2 Basal Anhydrite Member are considered part of the brittle basement (Van Gent et al., 2010) that also includes the Rotliegend and underlying Carboniferous and older basement rocks.

Accurate mapping of the $\mathrm{Z} 3$ stringer, a dolomite-anhydrite layer at the base of the $\mathrm{Z} 3$ Leine Formation, allows distinction between the thick Z2 and Z3 salts (Van Gent et al., 2010) and demonstrates the complex ductile behaviour of the surrounding salt layers. Traditionally, the Z2 Salt Mb. is considered the most important contributor to salt diapirism, although the variable position of the $\mathrm{Z} 3$ stringer (sealing or welding) with respect to the top or base of the Zechstein group indicates that Z3 salt flowed considerably as well (Fig. 3b). Therefore both Z2 and Z3 salt are considered the key contributors to salt diapirism. This is confirmed by well data, which show that either Z2 or Z3 salts form the core of diapirs (Geluk et al., 2007 and references therein). Internally, such thick salt packages may have mechanical layering (Urai et al., 2008); the possible effects on salt diapirism are beyond the scope of this paper.

Where the Z2 salt is completely removed, the Z3 stringer is welded downward to the top of the Base Z2 Anhydrite. Sealing of the Z3 stringer to the Zechstein Upper Claystone may have been caused by removal of the $\mathrm{Z} 3$ salt. Complete welding of all non-salt layers indicates that both Z2 and Z3 salts have been removed (Fig. $3 \mathrm{~b}$ ). In this case, it is difficult to determine the origin of the salt (Z2 or Z3).
The Z4 salt (Aller Formation) is only found in isolated depocentres where it may reach a thickness of up to $150 \mathrm{~m}$ (Geluk, 1999). A relatively thick interlayer of highly mobile potassium-magnesium salts suggests that the salt is ductile. Its limited thickness outside the few depocentres implies that Z4 salt flow is only of local importance. The thickness of Z5 is maximally $15 \mathrm{~m}$ (Geluk, 2007) and considered a relatively unimportant contributor to salt diapirism, although it may have acted as detachment plain accommodating horizontal strain.

\section{Estimation of original salt thickness}

Thickness variations observed in the ZE group are predominantly determined by salt structures made up of Z2 and/or Z3 salt. Compared to salt thickness, the intercalated carbonate and anhydrite layers are relatively uniform in thickness (Geluk, 2000; 2007). Due to halokinesis, salt layer thicknesses (and also the thickness of the non-salt layers) in the wells available for this study are mostly not representative for the depositional thickness. Since the regional seismic mapping of the Dutch offshore (NCP2; Kombrink et al., this issue) only mapped the base and top of the ZE Group, neither structured- nor depositional salt thicknesses can be estimated for the individual Zechstein salt layers. Thus, the available information on depositional salt thickness is scarce. In order to be able to estimate the original ZE thickness, an approach is presented here that focuses on redistributing the thickness of the entire ZE Group by removing the salt-flow effects. The distribution of salt thickness based on available well stratigraphy was calculated in the same way. The workflow is described in 3 steps:

\section{Step 1}

Figure 4 shows a cross-section of the main Dutch offshore salt province from the Cleaverbank Platform in the west, via the Dutch Central Graben and the Terschelling Basin to the Ameland Platform in the east. This cross-section shows that the average wavelength of the salt structures is $\sim 10 \mathrm{~km}$ and that salt walls, diapirs and pillows are closely linked to basement faults (e.g. Remmelts, 1995, 1996). This suggests that the salt did not flow (far) beyond the limits of the basin compartments, supporting the notion that activity along the main basement faults triggered and focused the generation of salt structures. Therefore, the total thickness of the ZE Group is restored by using half the fault block wavelength $(5 \mathrm{~km})$ as an estimate for the maximum flow distance towards the salt structure and the loci of the subsalt faults. This number was assigned to the width of the moving window that was used to remove the salt-flow effect by applying iterative mean smoothing (Fig. 4). The advantage of mean smoothing is that unrepresentative peaks in the thickness data, such as in salt diapirs, are acknowledged in the resulting thickness value of its neighbourhood, whereas median smoothing would suppress these too much. As such, volume balance is guaranteed to a better extent. The resulting thickness 


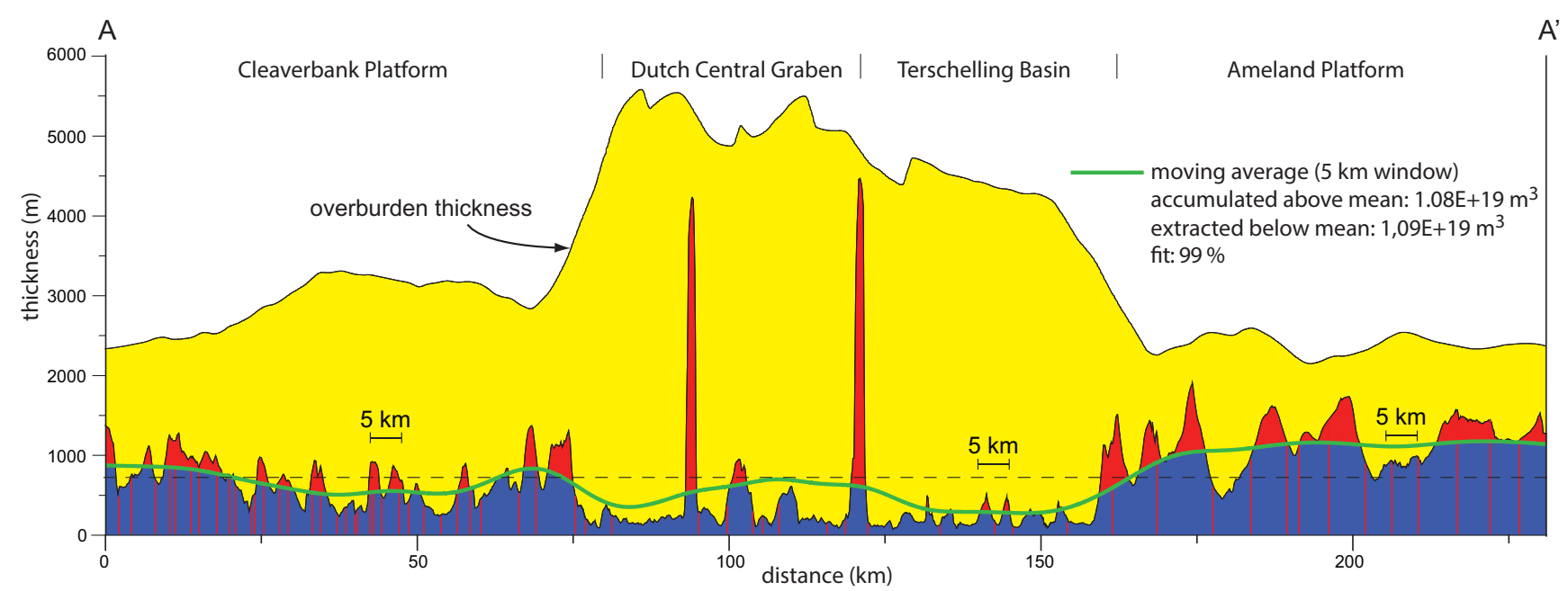

Fig. 4. Cross-section (locality shown in Fig. 1) with salt thickness anomaly relative to restored mean thickness (green line) showing a 99\% fit between salt withdrawal and accumulation. Red vertical lines show the position of mapped faults in the underburden of the Zechstein salt.

distribution is considered to represent the original depositional (not decompacted) thickness. By plotting the standard deviation (SD) for each iteration, it shows that after 24 runs the SD stabilises while it decreases by less than 1\% (Fig. 5). Therefore the results of the $25^{\text {th }}$ run are considered the best fit, since further smoothing did not provide significant changes. Note that before the SD's could be plotted, the general N-S thickness trend of the ZE was subtracted. This trend has a much higher wave length than the $5 \mathrm{~km}$ adapted for the salt structures and was obtained by smoothing over $200 \mathrm{~km}$ i.e. the approximate N-S extent of the ZE Group in the studied area. The depositional thickness on the less-disturbed platform areas is around 1000 m and corroborates earlier estimates (e.g. Remmelts, 1996).
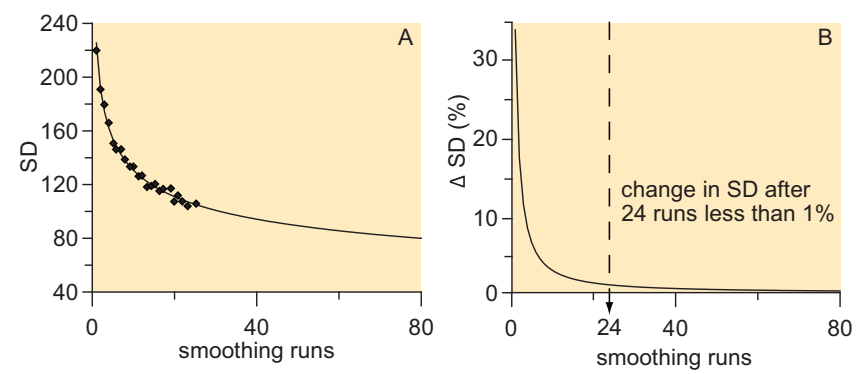

a.

b.

Fig. 5. a. Standard deviation (SD) of Zechstein Group thickness vs smoothing iteration number; $b$. Change in SD vs smoothing iteration number.

\section{Step 2}

Subsequently, a thickness anomaly map was created (Fig. 6) based on the total ZE thickness compared to the smoothed results, highlighting local variations in salt thickness and depicting the degree of salt flow. The anomaly maps nicely shows the difference in anomaly values for different structural elements identified (Kombrink et al., this issue) and shows areas of salt accumulation (red) and depletion (blue) relative to the original thickness. This approach thus reveals the degree of deformation associated with the sub ZE faults.
The totals of positive and negative deviations (anomalies) from the thickness after 25 smoothing runs (Fig. 4) show a $99 \%$ fit. This fit only refers to the smoothing method applied. However, it may give the (false) impression that no dissolution or flow outside the area of investigation occurred and that salt deformation can be fully explained by the down-building model of Cartwright et al. (2001; Fig. 6a). However, salt piercing may have led to emergence and dissolution and may even have been redeposited during later (e.g. Röt and Muschelkalk) evaporitic phases. The presence of cap rocks on crests of many of the salt diapirs is traditionally seen as an indication of such 'superjacent' dissolution (Gussow, 1968). But modes of lateral dissolution could have taken place as well and can be responsible for removal of as much as $40 \%$ of the original Zechstein volume from the basin and may account for much of the saltrelated deformation (Cartwright et al., 2001 and references therein; Fig. 6b). If the dissolution mode would have been totally responsible for the salt structuration, the original salt thickness would have been greater and approximately 50\% dissolution should have taken place (Fig. 6b). This number is rather high compared with the $30 \%$ volume loss for the Central North Sea Basin suggested by Bishop et al. (1995). This lower number may be an expression of a combination between downbuilding and dissolution mode(s) of salt deformation. Since it is hard to discriminate between both modes, the calculated depositional thickness should be seen as a minimum figure. Apart from dissolution, locally the salt was severely eroded, as is evidenced by a clear angular unconformity between the Zechstein Group and Cretaceous associated with Early Cretaceous fault-block tilting along the Elbow Spit High - Step Graben boundary fault (Remmelts, 1996).

\section{Step 3}

In order to estimate the depositional thickness of the salt layers in the ZE Group, the smoothing operation mentioned above was also performed using the 1351 wells that contain one or more 


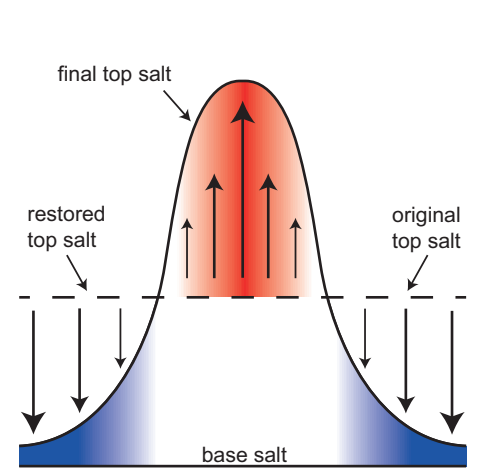

a.

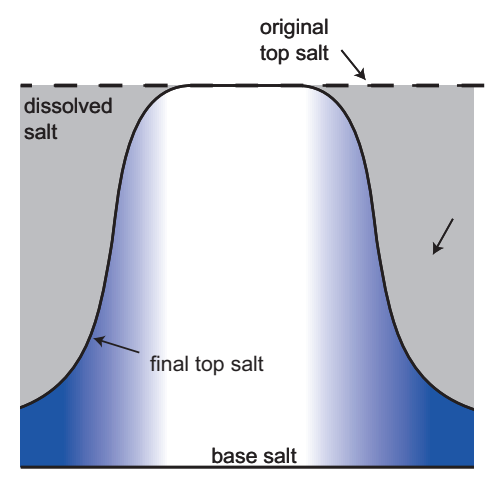

b.

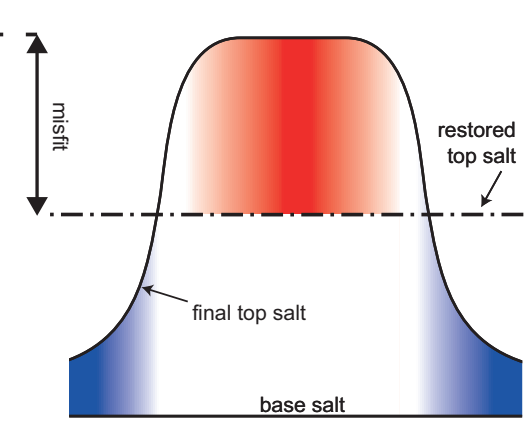

c.

Fig. 6. Relationships between modes of salt withdrawal (blue) and accumulation (red) relative to the original salt top for different kinematic evolutions of salt structures (modified after Cartwrigth et al., 2001). Halokinetic intensity is indicated with colour shading. a. Down-building model where salt from the flanks flows into the diapir and volume is preserved; and b. Dissolution model with stationary salt top, and (in this case) almost complete dissolution of salt that originated from the flanks and accumulated above the depositional reference level. c. Explanation of how the here-presented method underestimates the depositional salt thickness (dashed line) by up to $50 \%$ in case $100 \%$ dissolution would be appropriate.

of the Z2, Z3, or Z4 salt layers. The smoothing removes the local effect of (salt) tectonics and results in a distribution of original total salt thickness (Fig. 7) that agrees well with the overall south-to-north thickening trend, previously described by Geluk $(2005,2007)$. This result, however, should be seen as a very rough estimate only, which can subsequently be used to estimate the proportion non salt vs salt layers. Information on the presence and thickness of salt layers can be used to study the distribution of the different fault types identified.

\section{Fault distribution vs salt thickness}

\section{Fault database analysis}

As part of the regional mapping program, numerous faults were mapped which together with the nine mapped stratigraphic layers form the basis of the structural model of the Netherlands' subsurface (see Kombrink et al., this issue). A total of 3847 interpreted faults are extracted from the structural model and stored as 3D geometries in a 3D spatial database (PostgreSQL extended with PostGIS). Besides the fault geometries, several attributes such as length, average strike and dip and stratigraphic units affected are stored. This enables the selection of faults based on location (relative to other faults) or attributes or a combination of both. The selection criteria for generation of extracted fault groups are listed in Table 1. The selected geometries plus the attributes can then be exported to different file formats for further analysis or representation. At present only offshore faults are stored in the fault database.

\section{Sub ZE faults}

This fault group represents 2650 mapped faults that either terminate upward in salt layers of the Zechstein Group or older Permian (Carboniferous) rocks (Fig. 3b). As shown in the rose diagram of Fig. 9 it is clear that NW-SE faults dominate, but

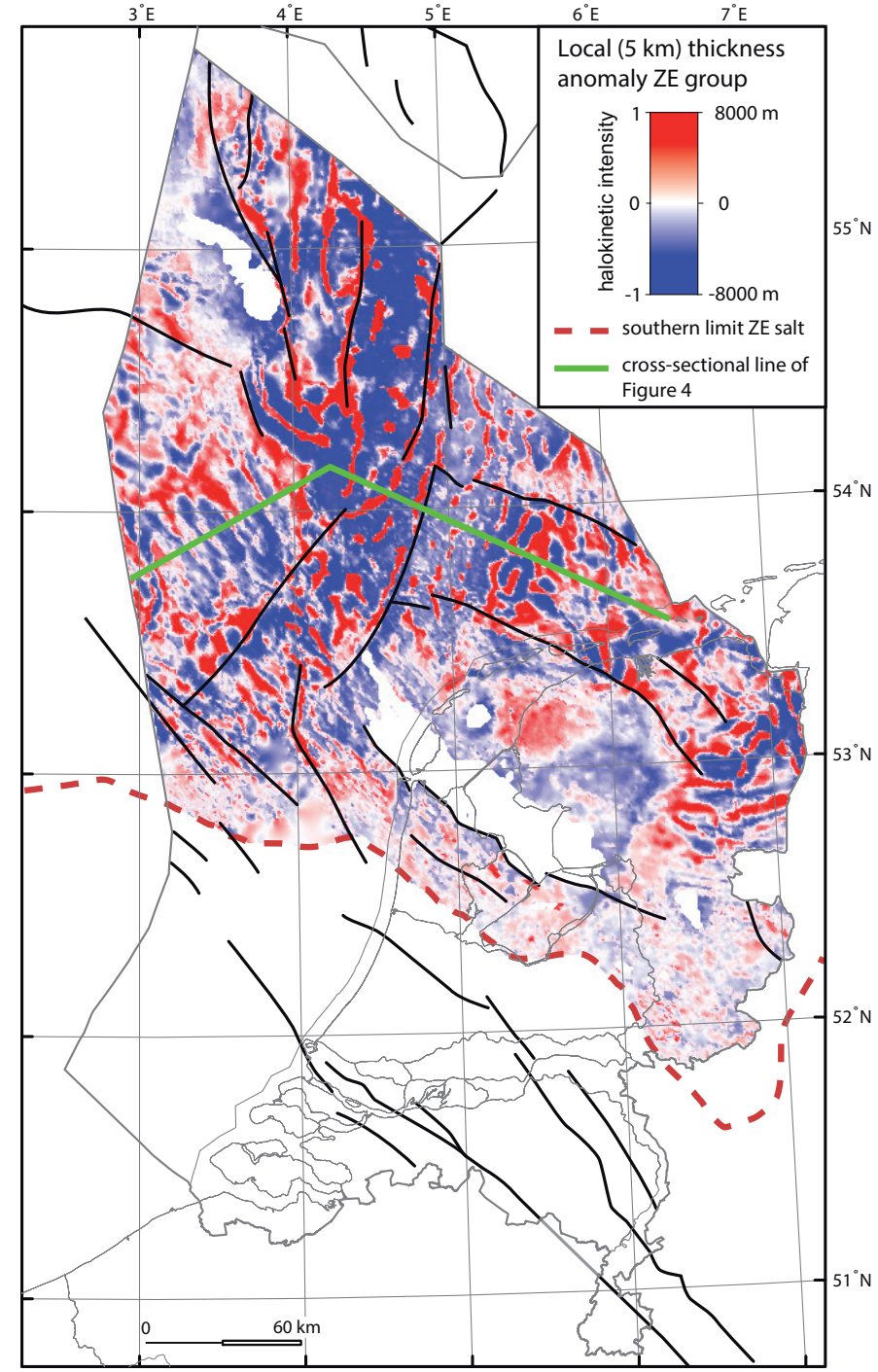

Fig. 7. Thickness anomaly map of the ZE group, used here to highlight spatial differences in halokinetic intensity (normalised anomaly between -1 and 1) of the ZE salt. Main tectonic features and structural elements as in Fig. 1. 
Table 1. Fault groups and their selection criteria. Stratigraphic units as in Figs 1 and 3.

\begin{tabular}{|c|c|c|c|}
\hline Group/subgroup & Base unit & Top unit & Remark \\
\hline 1. subZE & PreZE or RO or ZE & ZE & Faults that terminate upward in ZE salt (where salt is thick) \\
\hline 2. Hard-linked faults & PreZE or RO or ZE & All units above ZE & $\begin{array}{l}\text { Faults originating below salt (as group 1) but also affecting } \\
\text { youngest units (where salt is thin or absent) }\end{array}$ \\
\hline $\begin{array}{l}\text { 3. supraZE a. Soft-linked faults } \\
\text { (salt <300 m) } \\
\text { b. Unlinked faults } \\
\text { (salt }>300 \mathrm{~m})\end{array}$ & ZE or RB & $\mathrm{KN}, \mathrm{CK}, \mathrm{NU}, \mathrm{N}$ & $\begin{array}{l}\text { Faults that are spatially linked to salt structures and their associated } \\
\text { sub salt faults, but are not connected with them (may be inverted) } \\
\text { faults that are not linked to subsalt faults, but which maybe } \\
\text { linked to salt structures (may be inverted) }\end{array}$ \\
\hline
\end{tabular}

that in general fault orientations range between E-W to NNESSW, making up rhombic to orthogonal fault patterns. The longer regional faults do not have a preferential orientation.

\section{Hard-linked faults}

The hard linked faults predominantly occur south of the axis of BFB and dominate the structural style of the WNB both off- and onshore (Fig. 3a). At the onlap against the London Brabant Massif the ZE Group is relatively thin and consists of an alternation of carbonate-anhydrite platforms and sandy- and muddy sabkha facies, originally deposited at the southern rim of the SPB. Here, rocksalt (halite) is not present. However, the distribution of the hard-linked faults shows that this group continues further north than the southern limit of rock salt, suggesting that a certain salt thickness can be involved with this fault group (Fig. 7). Hard-linked faults are abundant if the salt is thinner than $200 \mathrm{~m}$ and are absent where the total ZE salt thickness exceeds $300 \mathrm{~m}$ (Fig. 3a). Empirically, the 200-300 m interval may therefore be considered the critical interval for transition between thin- and thick-skinned salt tectonics. Based on a fault database analysis of the offshore hard-linked faults (Fig. 9b), it is shown that 286 mapped high-angle (60-90 dip) faults belong to this group. Most of the faults have a NW-SE orientation and are connected with fault segments of slightly different orientation in an en-echelon or anastomosing arrangement. A small number of faults is N-S to NNE-SSW oriented.

\section{Supra ZE faults where salt is thinner than $300 \mathrm{~m}$}

This group includes normal and reverse faults that commonly sole in the salt layers of the Zechstein (ZE) or Triassic (RN). Although not connected, these faults show a close spatial relation with faults below the Zechstein group and are therefore classified as 'soft-linked' faults. In seismic data these faults often show reversed fault offsets, suggesting that they were subject to inversion tectonics. For instance, the southern margin of the BFB (Fig. $3 \mathrm{~b}$ ) is, at present, marked by a complex reverse/thrust fault zone that utilised both Triassic and Zechstein salt as detachment levels. Figure 9d shows that these faults have rather uniform NW-SE orientations, comparable to those of the hard-linked faults. Also in mapview the faults display a similar en-echelon to anastomosing pattern.

\section{Supra ZE faults where salt is thicker than $300 \mathrm{~m}$}

This group represents faults that are not linked to subsalt faults, but which may be related to salt accumulation or withdrawal structures. The random distribution of fault orientations (Fig. 9c) can be explained by radial fault patterns that are a common feature in the overburden of the salt diapir roof domain (cf. Stewart, 2007). Faults in the salt withdrawal zones (in between salt structures), indicate the local brittle adjustment of the salt overburden (Fig. 10a) due to formation of rim synclines and turtle-back structures.

\section{Relation between salt and fault distribution}

This study underlines the importance of thick (>300 m) salt in the generation and (re)activation of faults in the under- and overburden. The results of the fault distribution analyses are in agreement with studies on more limited datasets carried out earlier (see for instance Nalpas et al., 1995; Racero-Baena \& Drake, 1996; De Jager, 2007). As far as the depositional salt thickness is concerned, the following can be deduced:

- Regionally, the fault patterns vary significantly: en-echelon to anastomosing in the south and rhombic to orthogonal in the north.

- In the southern offshore where salts are thin the overburden shows the same fault pattern throughout the stratigraphic sequence. This suggests that the same faults were reactivated multiple times and under different stress conditions (e.g. De Jager, 2007 and references therein).

- In the northern realm, where salt is thicker than $300 \mathrm{~m}$, the strain patterns in the supra-salt succession are only faintly related to sub-salt patterns. The dominance of NW-SE faults is recognisable, but this group represents a large amount of reverse faults along the inverted northern boundary of the Broad Fourteens Basin. These faults are not directly related to sub salt structures, which further suggests that during the 


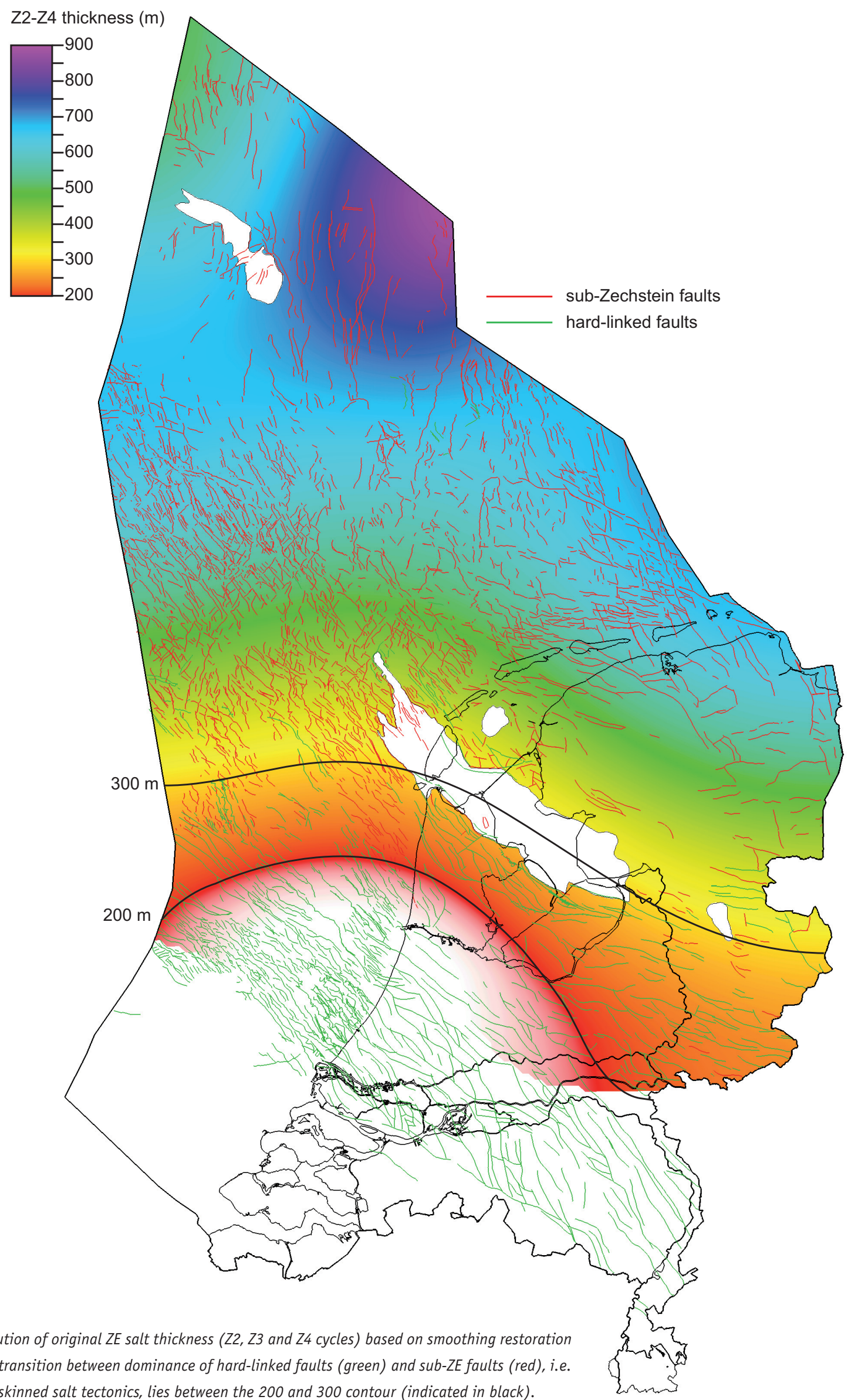

Fig. 8. Thickness distribution of original ZE salt thickness (Z2, Z3 and Z4 cycles) based on smoothing restoration as described in text. The transition between dominance of hard-linked faults (green) and sub-ZE faults (red), i.e. between thick- and thin-skinned salt tectonics, lies between the 200 and 300 contour (indicated in black). 
Fig. 9. Rose diagram of faults represented as length-strike data. RHR rule is applied, i.e., the NW and SE quadrants show NE and SW dipping faults respectively. Inner circles at every $5 \%$ of total data. a. Sub Zechstein normal (red) and reverse (yellow) faults; b. Hard linked normal (red) and reverse (yellow) faults classified according fault type; c. supra ZE faults where salt $>300$ ); d. supra ZE faults where salt $<300 \mathrm{~m}$. Faults are classified according stratigraphic unit in which the faults sole: 1 =Zechstein Group, 2 = Lower Germanic Triassic, 3 = Upper Germanic Triassic, $4=$ Lower and Middle Jurassic, $5=$ Upper Jurassic, $6=$ Lower Cretaceous, $7=$ Upper Cretaceous, $8=$ Cenozoic.

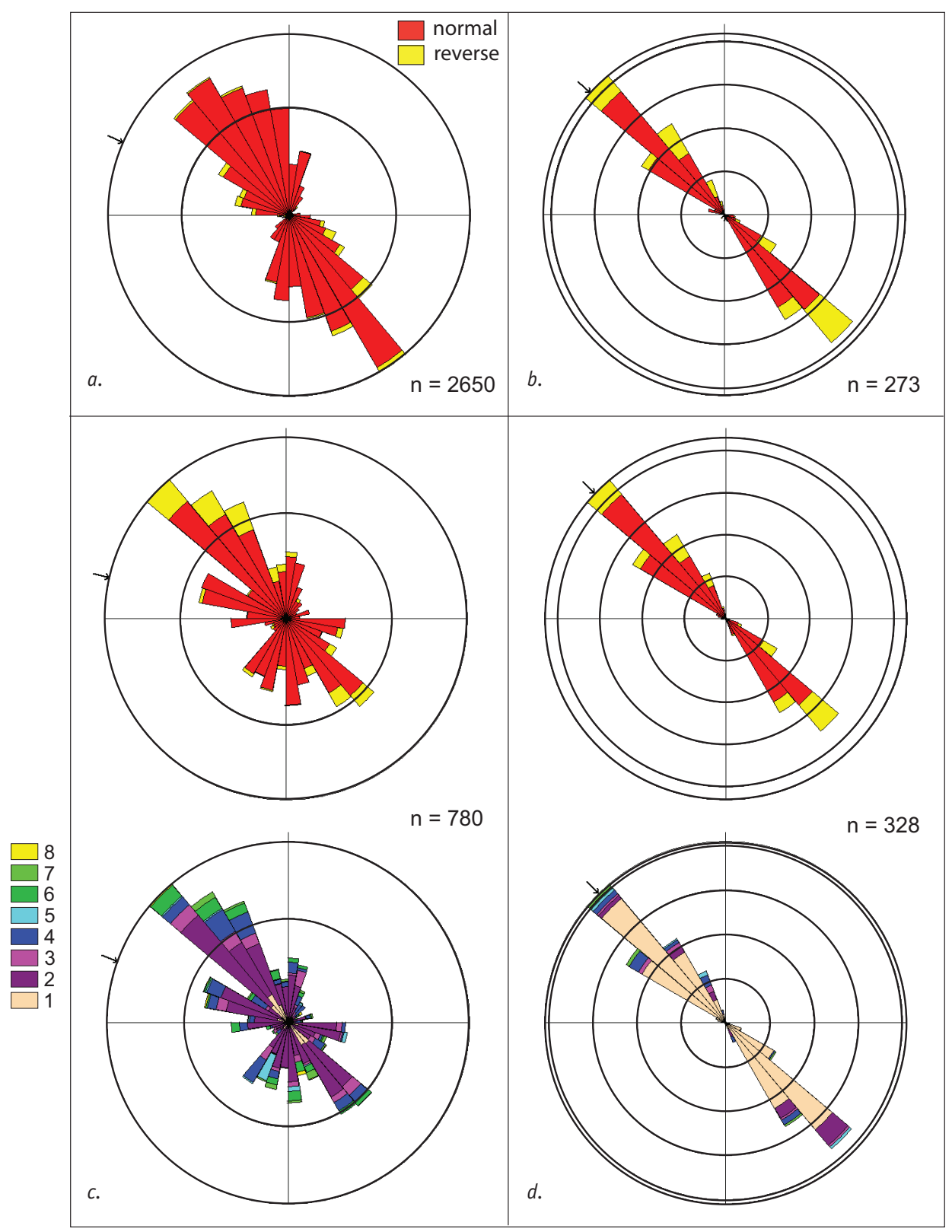

inversion phases the thick salt layer acted as decollement level (De Jager, 2003). Some NW-SE-trending (north-vergent) reverse faults have been observed in the Carboniferous and Rotliegend (Schroot \& De Haan, 2003) that were attributed to the main (Sub-Hercynean) phase of inversion. Most inversion structures, however, are observable above the salt, where the amount of shortening that is accommodated is in apparent excess of the shortening accommodated by sub-salt faults. The majority of the overburden faults are randomly orientated and secondary to the generation of salt structures. Deformation is thus concentrated in the salt structure and in the sedimentary sequence above, as has been deduced for other regions in the Southern Permian salt Basin too (e.g. the Central European Basin; Mohr et al., 2005).

- Locally in the northern sector, for instance at the margins of the Central Graben, displacement at sub-ZE faults grew to over several kms. Here it is evident that, through continuous salt withdrawal, the thin-skinned system evolved into a thick-skinned one with faults that cut the entire basin fill succession.

- In the northern realm, below the thick salt a systematic rhombic to locally orthogonal fault pattern plays an important role in the compartmentalisation of the Rotliegend reservoirs. In combination with the ZE salt, which forms the most important seal, this explains why the distribution of successful R0 plays is limited to the area north of the $300 \mathrm{ZE}$ contour. South of this contour, the sealing capacity of the thin salt layers is negatively affected by hard-linked faults that transect the ZE Group. The northern extent of the R0 fields is limited by distribution of RO reservoir sands (northern sand limit; De Jager \& Geluk, 2007). 


\section{Role of overburden and timing of salt flow}

\section{Halokinetic intensity}

Halokinetic intensity (Fig. 7) varies significantly across the master fault zones that bound the structural elements (see Kombrink et al., this issue for their definition). Based on the salt flow intensity, a twofold division can be made between platforms/highs and basins (Fig. 1): on the platforms/highs salt structures occur exclusively as pillows and ridges, whereas in the basins they are characterised by giant salt domes and ridges that are more elongated than on the platforms.

It is interesting to note that differences in halokinetic intensity highlight structural features that were previously regarded as less important. For instance, the transition zone between the Ameland Platform and the Terschelling Basin was previously seen as a local fault in between the Hantum and Rifgronden faults that played a role in the facies distribution of the Lower Germanic Trias Group and the Sollingen sandstone of the Upper Germanic Trias Group (see Geluk, 2007 and references therein). The linear jump in halokinetic intensity also transects the SGP, suggesting a more regional importance of a zone that plausibly connects to the Horn Graben (Fig. 1).
Generally, it can be stated that the strong lateral variation in halokinetic intensity relates to differences in structural development and is also reflected by the thickness distribution of the Zechtstein overburden, i.e. those units deposited during the periods of salt flow (see Fig. 4). This supports the notion that a genetic and temporal relation exists between the thickness of the overburden and intensity of halokinesis and that both were genetically related to the same tectonic process. For instance, intense stretching during the Mid-Kimmerian tectonic phase facilitated the deepening of the Jurassic grabens due to pronounced offset at the basin margin faults (often sub salt faults), which also triggered the salt mobilisation. This notion is supported by numerous rim-synclines adjacent to salt structures that exhibit internal unconformities constraining the timing of salt-induced upwarp and folding.

Good examples of this phenomenon can be seen at the western margin of the DCG where two phases of salt diapirism can be inferred from rim syncline stratigraphy and unconformities (Fig. 10). In this example, the uniform thickness of the Triassic sequence suggests that the basin fill was not affected by (major) salt tectonics at times of deposition. The rapidly westward thinning and onlapping Jurassic sequence together with several internal unconformities in the Upper Jurassic rocks (Fig. 10)
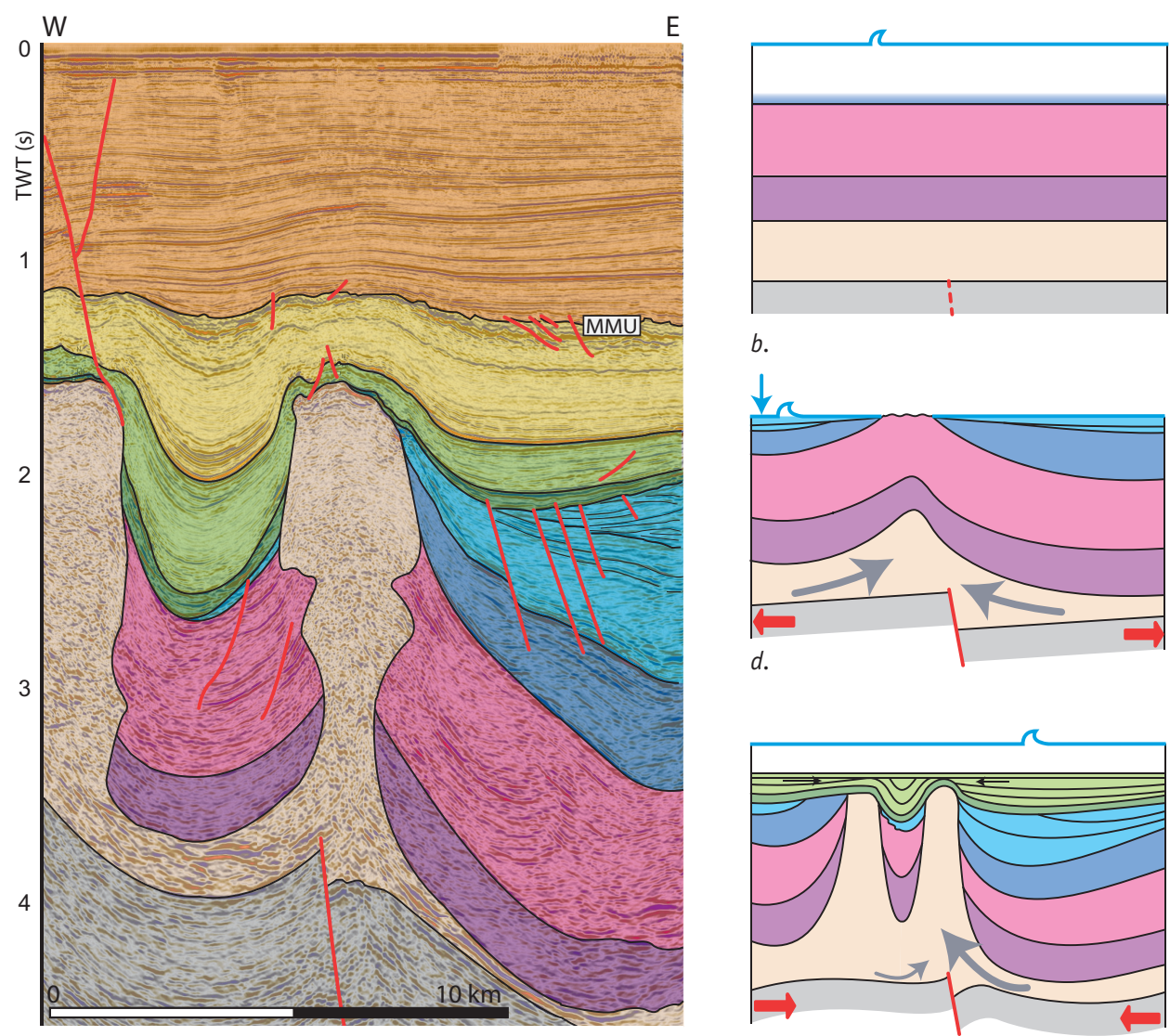

$b$.
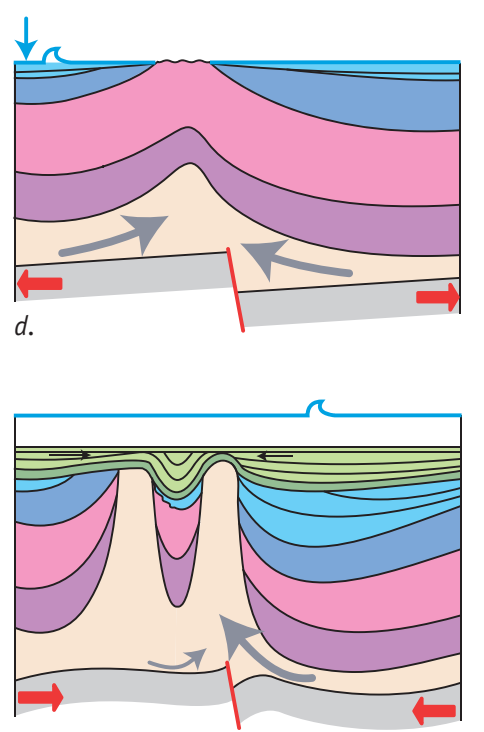

$f$.

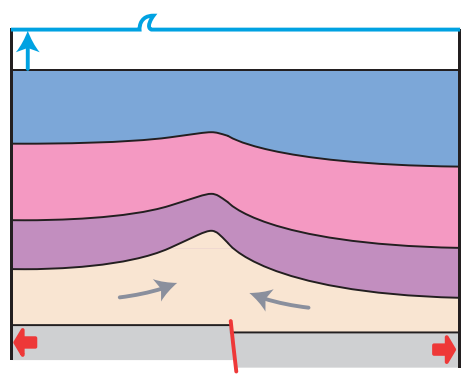

c.
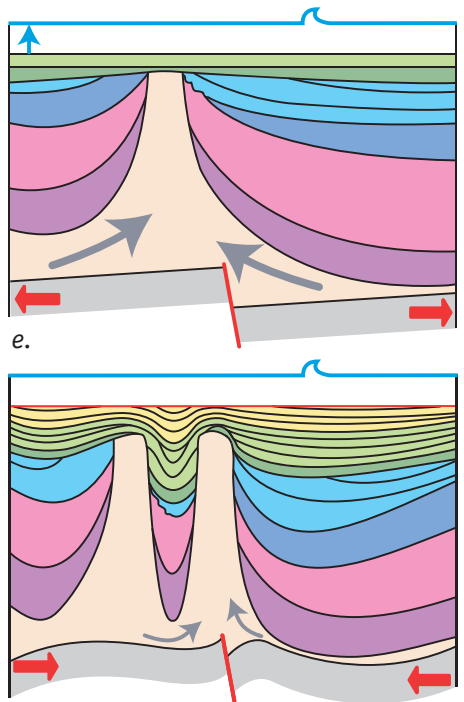

g.

Fig. 10. a. seismic section in TWT with interpretation, $b$-g: reconstructed evolution of salt diapirism with arrows proportional to halokinetic intensity, time steps correspond to phase of significant tectonism: b. Early Kimmerian; c. Mid-Kimmerian; d. Late Kimmerian phase 2; e. relative tectonic quiescence during Cenomanian; f. Sub-Hercynean inversion; g. combined effects of Laramide and Pyrenean inversion. Stratigraphic codes as in Figs 1 and 3. Vertical scale is approximate. 
attests to syn-salt tectonic sedimentation. This occurred during the Mid-Kimmerian tectonic phases that led to differential deepening of the DCG. Piercing of the westward onlap contact by the eastern diapir suggests that this dome formed later, most probably during the Turonian onset of compression. The dome is covered by Late Cretaceous deposits of the Chalk Group that are folded and show strong thickness variations related to rim-syncline formation adjacent to the western dome. The difference in folding style below and above the MMU shows that folding and uplift also continued during the later Laramide and subsequent Pyrenean-Savian inversion phases.

\section{Backstripping analysis}

The temporal variations in halokinetic intensity can be further analysed by a back-stripping (burial history) analysis of the basin infill. Two representative profiles for both platform/high and basin settings were selected, which were extracted from 3-dimensional backstrip analysis studies of the Cleaverbank Platform (Abdul Fattah et al., 2012) and the Dutch Central Graben/Terschelling Basin (Verweij et al., 2009). Table 2 shows the parameters used for this exercise, which include timing and duration of periods of sedimentation, erosion and nondeposition from the Late Carboniferous to present-day.

\section{Erosion}

The thickness of the eroded sediments was reconstructed for two main periods of erosion, namely the Mid-Kimmerian (mainly erosion on platforms and basins) and Sub-Hercynian (uplift and erosion of basins) phases. Earlier phases of erosion, e.g. the Carboniferous Saalian phase, were not taken into account. In order to estimate erosion, first the original thicknesses of missing stratigraphic units was estimated using the top Rotliegend map, the new thickness maps of the stratigraphic units (e.g. Kombrink et al., this issue) and detailed stratigraphic information from the new well log interpretations in the study area (Verweij \& Witmans, 2009), in combination with regional knowledge and information on palaeogeography, sedimentary and structural history (e.g. De Jager, 2007; Geluk, 2007; Van Buggenum \& Den Hartog Jager, 2007). Estimated erosional thicknesses were verified with $1 \mathrm{D}$ basin modelling at well locations. The estimated initial thicknesses of stratigraphic units and erosional thicknesses is described in the following sections.

\section{Erosion in the Dutch Central Graben - Terschelling Basin}

Mid-Kimmerian erosion concentrated in the Terschelling Basin and on the platforms and highs and affected both the Altena Group and the Upper Germanic Trias groups. The original thickness of the Altena Group was estimated at $600 \mathrm{~m}$ in the Terschelling Basin (present-day thickness $=0 \mathrm{~m}$ ) and at least $600 \mathrm{~m}$ in the Dutch Central Graben. Due to syn-depositional salt tectonics, locally the Altena Group may be $>1000$ m thick or completely absent (Verweij et al., 2009). The original thickness of the Lower Germanic Trias Group was at least $800 \mathrm{~m}$ in the Terschelling Basin (present-day thickness varies between 0 and $>1000 \mathrm{~m}$ ) and at least $800 \mathrm{~m}$ in the Dutch Central Graben (present-day thickness varies between 0 and $>1500 \mathrm{~m}$ ).

The scenario for Cretaceous and Danian sedimentation and intermittent Sub-Hercynian erosion includes the following steps: 1) the assumed pre-erosional thickness of the Chalk Group is constant $(400 \mathrm{~m}) ; 2$ ) the assumed short period of Sub-Hercynian erosion in the Cretaceous is concentrated in the Dutch Central Graben and affects the Chalk and Rijnland groups (maximum erosion 400 and $300 \mathrm{~m}$, respectively); and 3) deposition of Chalk Group sediments resumes after erosion with thicknesses varying between $0 \mathrm{~m}$ (i.e. non-deposition) in the uplifted eroded centre of the graben to more than $600 \mathrm{~m}$ away from the centre.

Table 2. Timing and duration of periods of sedimentation, erosion and non-deposition (in bold italics) used for backstripping analysis; same colour coding applied as in Figs 3, 11 and 12.

\begin{tabular}{|c|c|c|c|c|c|c|c|c|c|}
\hline \multicolumn{2}{|c|}{ Layer } & \multicolumn{4}{|c|}{ Cleaver Bank Platform } & \multicolumn{4}{|c|}{ Dutch Central Graben - Terschelling Basin } \\
\hline & & \multicolumn{2}{|c|}{ Deposition age (Ma) } & \multicolumn{2}{|c|}{ Erosion age (Ma) } & \multicolumn{2}{|c|}{ Deposition age (Ma) } & \multicolumn{2}{|c|}{ Erosion age (Ma) } \\
\hline & & From & To & From & To & From & To & From & To \\
\hline 1 & Quaternary & 1.81 & 0 & 0 & 0 & 1.81 & 0 & 0 & 0 \\
\hline 2 & Pliocene & 5.33 & 1.81 & 0 & 0 & 5.33 & 1.81 & 0 & 0 \\
\hline 3 & Miocene & 20.43 & 5.33 & 0 & 0 & 20.43 & 14.80 & 0 & 0 \\
\hline 4 & Middle and Lower North Sea Group & 56.8 & 30.4 & 0 & 0 & 56.8 & 30.4 & 0 & 0 \\
\hline 5 & Chalk & 99.1 & 61.7 & 0 & 0 & 99 & 61.7 & 83.5 & 80.50 \\
\hline 6 & Rijnland Group & 124 & 99 & 0 & 0 & 140 & 99 & 80.5 & 80 \\
\hline 7 & Schieland Group & 154 & 140 & 0 & 0 & 154 & 140 & 0 & 0 \\
\hline 8 & Altena Group & 204 & 173 & 173 & 170 & 204 & 176 & 176 & 157 \\
\hline 9 & Upper Germanic Trias Group & 245 & 203.6 & 170 & 165 & 245 & 203.6 & 162 & 154 \\
\hline 10 & Lower Germanic Trias Group & 254 & 245 & 165 & 153.87 & 254 & 245 & 0 & 0 \\
\hline 11 & Zechstein Group & 258 & 254 & 0 & 0 & 258 & 254 & 0 & 0 \\
\hline 12 & Pre Zechstein Basement & 258 & 326.5 & 0 & 0 & 258 & 326.5 & 0 & 0 \\
\hline
\end{tabular}




\section{Cleaverbank Platform erosion}

This area was uplifted during the Late Jurassic (Mid- and Late Kimmerian erosion). The movement caused deep erosion and complete removal of the Lower to Middle Jurassic sediments as well as parts of the Triassic sediments. The eroded thicknesses of the Altena Group (AT), the Upper Germanic Trias Group (RN) and the Lower Germanic Trias Group (RB) are estimated assuming depositional thicknesses of $200 \mathrm{~m}, 400 \mathrm{~m}$ and $500 \mathrm{~m}$ respectively (Fig. 12) and are based on well data and regional stratigraphic correlations (Abdul Fattah et al., 2012). Sub-Hercynian inversion only mildly affected the Cleaverbank Platform and therefore erosion for this event was not incorporated.

\section{Salt flow}

Deformation of Zechstein salt is incorporated in the simulation of the burial history by using the 'salt movement' tool of Petromod $^{\circledR}$, which allows for lateral deformation of the sediments. Main inputs are the present-day thickness distribution of the (entire) Zechstein Group and the original depositional thickness. This original thickness of the Zechstein Group at the localities of the presented profiles was derived from the earlier presented thickness restoration and amounts to $700 \mathrm{~m}$ (Figs 11 and 12). Note that the location of the profiles was deliberately chosen in areas with approximately equal original thicknesses in order to focus on post-depositional differences in salt thickness. Salt movement was set to start in the Triassic, its speed and extent was determined by overburden effects. The analysis did not take into account the deformation of Upper Rotliegend and Upper Triassic evaporites.

\section{Interpretation of results}

Salt flow was more intense during periods that coincide with known tectonic phases, but the intensity differs largely between structural element types. On the platform areas, such as the Cleaverbank, the Schill Grund and Ameland Platforms, salt flow was minor and resulted in salt pillows only. Backstripping showed that sub-salt faulting and minor salt flow took place prior to the Late Jurassic and is predominantly related to Early - MidKimmerian extension. This is interpreted by the fact that the Platforms/Highs experienced less structural deformation during the major phases of Jurassic rifting. The thick Jurassic overburden common for the graben areas is absent, which precludes major salt flow during this and subsequent tectonic phases. Main salt flow was triggered during the Sub-Hercynian and later phases of compression and resulted in salt pillow geometries.

In the basinal areas, such as the Central Graben and Terschelling Basin, strong salt movement occurred, and salt domes and walls were formed. Salt flow occurred mainly during Late Kimmerian rifting, although it commenced during the
Early Kimmerian phase. Some flow occurred in response to Subhercynean inversion as well (De Jager, 2003). In the rift basins salt diapirs and walls are almost exclusively linked to major subsalt faults and occur where the Jurassic succession is thickest. Inversion structures (basins) on which the Cretaceous is thinning or absent are coupled to inverted subsalt structures (De Jager, 2003).

\section{Conclusions}

We present the results of a regional analysis of salt structures in the Netherlands part of the North Sea Basin as part of the offshore mapping project (NCP-2). For the complex relationship between salt structures, tectonic evolution and presence and type of overburden, two factors are of prime importance: firstly the thickness of the original Zechstein salt layer, followed by the type of structural element(s) involved.

- Where the salt exceeds $300 \mathrm{~m}$ halokinesis is thin-skinned in the sense that it is decoupled from subsalt faulting, i.e. strain is vertically partitioned. During phases of extension the stresses are exerted at deep, sub salt, crustal levels where deformation is mostly brittle. Above the salt layer deformation is reactive to the salt structuration and only indirectly related to the active stressfield. Provided that strain markers would be present on supra salt faults, stressinversion techniques can not be applied straightforwardly since they are informative for the local stress field around the salt structure only. For this reason, reconstructing strain from seismic data should focus on detecting phases of reactivation from subsalt faults rather than focusing on smaller, subsidiary faults in the supra salt cover.

- On the platform areas, such as the Cleaver Bank, the Schill Grund and the Ameland platforms, salt flow was minor and resulted in salt pillows only. Along the edges of the platforms, however, some diapiric structures have developed. Backstripping showed that sub salt faulting and minor salt flow took place prior to the Late Jurassic and is predominantly related to Early-Mid-Kimmerian extension. Platforms/Highs experienced less structural deformation during the major phases of Jurassic rifting and the absence of Jurassic overburden precludes major salt flow during this tectonic phase. Main salt flow was triggered during the Sub-Hercynian and later phases of compression resulting in salt pillow geometries. Regarding the periods of active salt flow, it is likely that salt piercing and dissolution on the platforms did not play a role and that the mean preserved thicknesses are more or less representative for the depositional thicknesses.

- In the basinal areas (the Dutch Central Graben, Step Graben and Terschelling Basin) strong salt movement occurred and salt domes and walls were formed. Main salt flow occurred during Late Kimmerian rifting, whereas some minor structuration occurred during Sub-Hercynian inversion. 


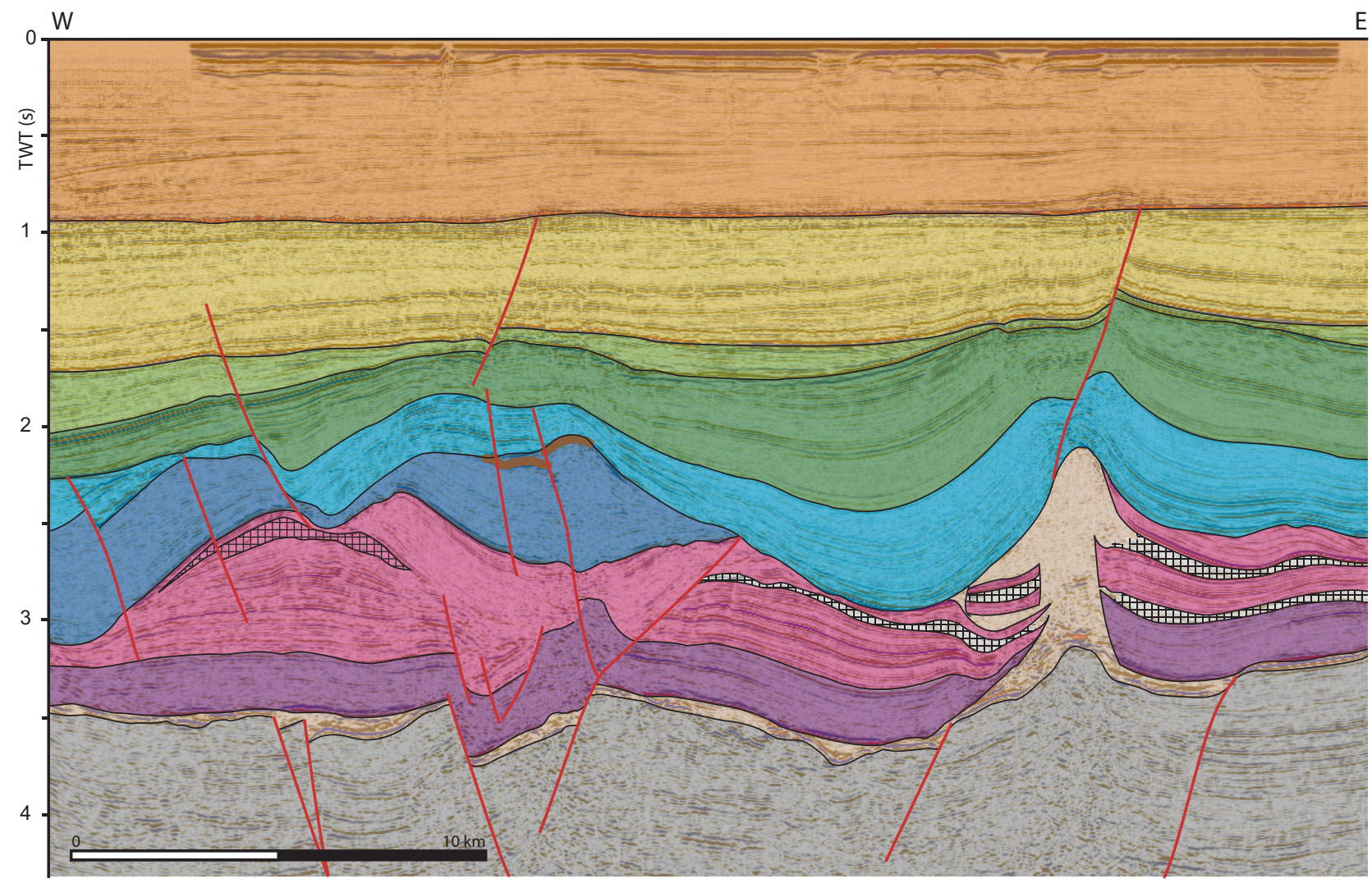

a.
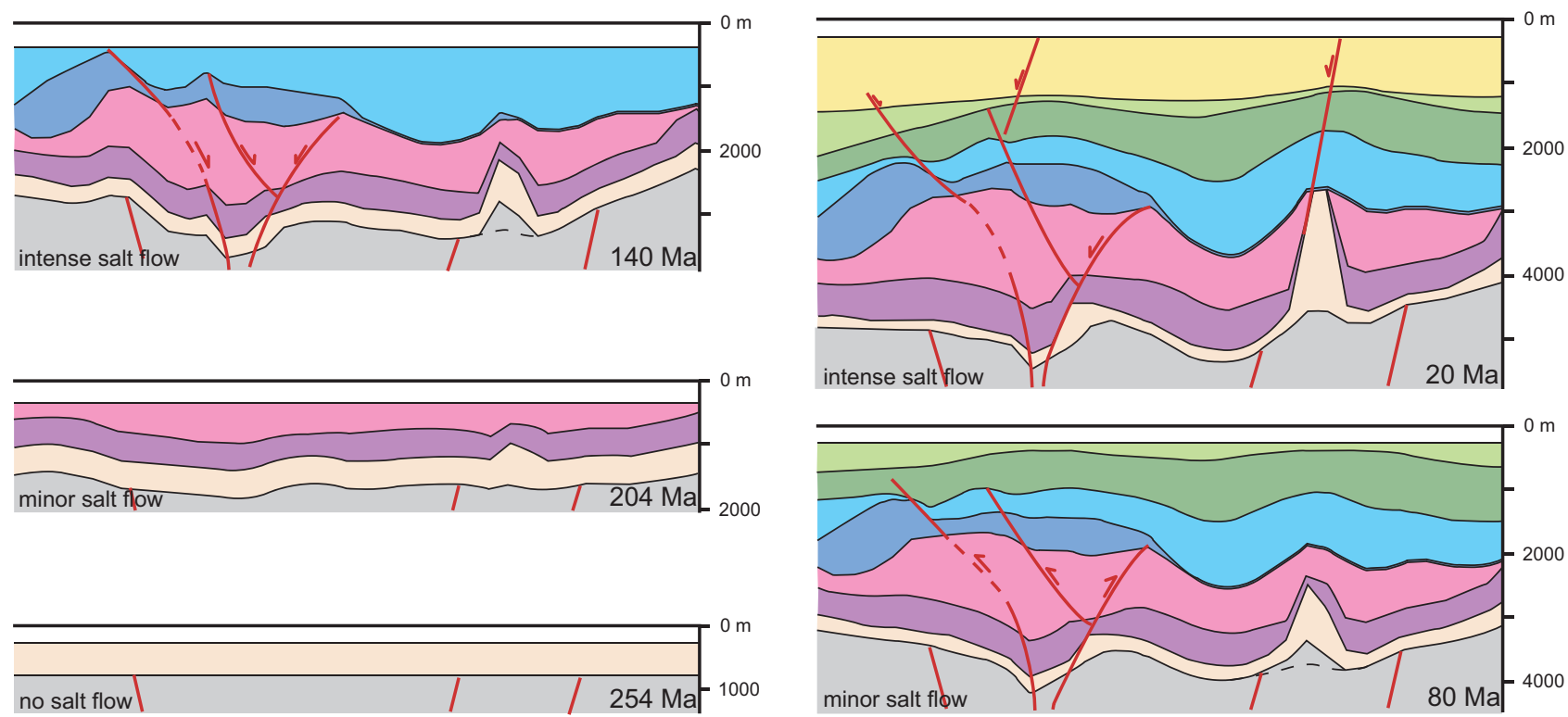

$b$.

Fig. 11. a. W-E seismic section across the Dutch Central Graben (see Fig. 1 for localities). b. 2D cross-section through 3D backstrip model results of Verweij et al. (2009; see text for details), showing 5 time steps that coincide with major regional tectonic events. 254 Ma= (end of) Hardegsen phase; 204 Ma = Early Kimmerian; $140 \mathrm{Ma}=$ Late Kimmerian phase; $80 \mathrm{Ma}=$ Sub-Hercynean phase; $20 \mathrm{Ma}=$ (onset of) Savian phase. Faults were not incorporated in the backstripping analysis (since it only performs vertical restoration), but drawn on the results at their approximate location (colour-coding as in Fig. 3).

In the rift basins, salt diapirs and walls are almost exclusively linked to major subsalt faults and occur where the Jurassic succession is thickest. Alternating movements on cross-cutting faults seem to be the reason for development of isolated salt domes opposed to the more common walls along the single fault trend. Inversion structures (basins) on which the Cretaceous is thinning or absent are coupled to inverted subsalt normal faults. Reconstruction of the depositional salt thickness involves a certain degree of uncertainty since it is 
a.
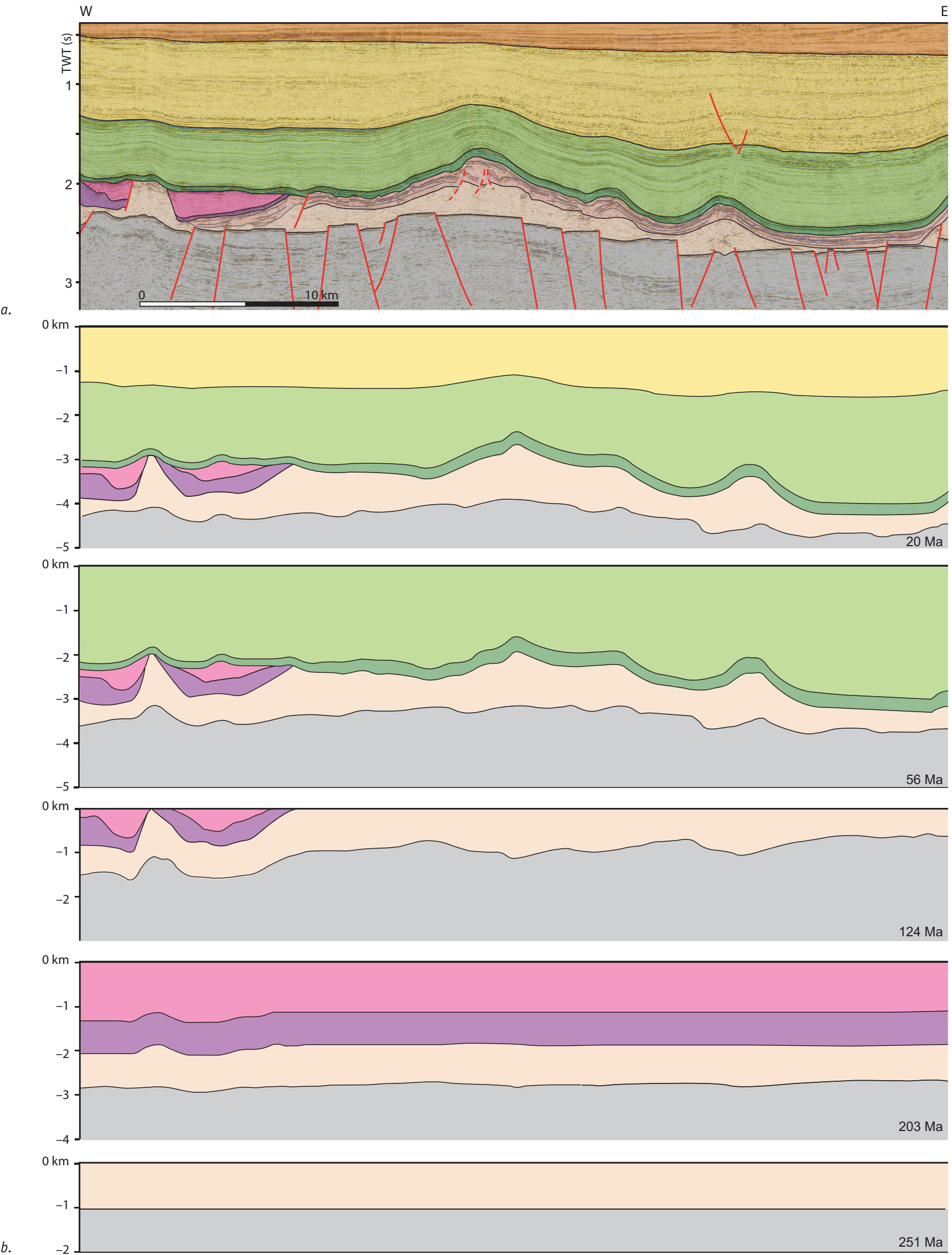

Fig. 12. a. W-E seismic section across the Cleaverbank Platform (see Fig. 1 for localities). b. $2 D$ cross-section through 3D backstrip model of Abdul Fatah et al. (2012; see text for details), showing 5 time steps that coincide with major regional tectonic events. $251 \mathrm{Ma}=$ (end of) Hardegsen phase; $203 \mathrm{Ma}=$ Early Kimmerian; $124 \mathrm{Ma}=$ Late Kimmerian phase; $56 \mathrm{Ma}=$ Pyrenean phase; $20 \mathrm{Ma}=$ (onset of) Savian phase. Faults were not incorporated in the backstrip analysis. 
unknown how much salt was dissolved during plausible salt piercing at the sea bottom. Also, the amount of redeposition during the Röt and Muschelkalk evaporitic phases, i.e. during periods of minor Early Kimmerian salt flow, is unknown.

- Where the salt is thinner than $300 \mathrm{~m}$, halokinesis is thickskinned, i.e. importantly controlled by subsalt faults that potentially transect the salt layer. For this reason most of the sub- and supra Zechstein faults show similar fault patterns. In the absence of decoupling salt layers the deformation associated with governing stresses is propagated through the entire rock succession.

\section{Acknowledgements}

We are grateful to all colleagues at TN0 that contributed to this study, through stimulating discussion or provision of data. Susanne Nelskamp is thanked for assistance with burial history analysis. An anonymous reviewer and Henk Kombrink are greatly acknowledged for providing thorough comments that significantly improved the final version of the paper.

\section{References}

Abdul Fattah, R., Verweij, J.M., Witmans, N. \& Ten Veen, J.H., 2012. Reconstruction of burial history, temperature, source rock maturity and hydrocarbon generation for the NCP-2D area, Dutch Offshore. TNO - Geological Survey of the Netherlands (Utrecht), Report number TN0-034-UT-2010-0223.

Bally, A.W., Bernouilli, D., Davis, G.A. \& Montadert, L., 1981. Listric normal faults. Oceanologica Acta 9: 7-101.

Bishop, D.J., Buchanan, P.G. \& Bishop, C.J., 1995. Gravity-driven thin-skinned extension above Zechstein Group evaporates in the Western Central North Sea: an application of computer-aided section restoration techniques. Marine and Petroleum Geology 12: 115-135.

Brun, J.P. \& Mauduit, T.P.O., 2009. Salt rollers: Structure and kinematics from analogue modeling. Marine and Petroleum Geology 26: 249-258.

Cartwright, J., Stewart, S. \& Clark, J., 2001. Salt dissolution and salt-related deformation of the Forth Approaches Basin, UK North Sea. Marine and Petroleum Geology 18: 757-778.

De Jager, J., 2003. Inverted basins in the Netherlands, similarities and differences. Netherlands Journal of Geosciences 82: 355-366.

De Jager, J., 2007. Geological development. In: Wong, T.E., Batjes, D.A.J. \& De Jager, J. (eds): Geology of the Netherlands. Royal Netherlands Academy of Arts and Sciences (KNAW) (Amsterdam): 5-26.

De Jager, J. \& Geluk, M.C., 2007. Petroleum geology. In: Wong, T.E., Batjes, D.A.J. \& De Jager, J. (eds): Geology of the Netherlands. Royal Netherlands Academy of Arts and Sciences (KNAW) (Amsterdam): 241-264.

De Jager, J., 2012. The discovery of the Lower Triassic Fat Sand Play (Middle Solling Sandstone), Northern Dutch offshore - a case of serendipity. Netherlands Journal of Geosciences 91-4: 609-619, this issue.

Dronkert, H., Nio, S.D., Kouwe, W., Van der Poel, N. \& Baumfalk, Y., 1989. Exploration and production potential of the Buntsandstein - Non Exclusive Study. Intergeos B.V., 450.
Geluk, M.C., 1999. Late Permian (Zechstein) rifting in the Netherlands: models and implications for petroleum geology. Petroleum Geoscience 5: 189-199.

Geluk, M.C., 2000. Late Permian (Zechstein) carbonate-facies maps, the Netherlands. Netherlands Journal of Geosciences 79: 17-27.

Geluk, M.C., 2005. Stratigraphy and tectonics of Permo-Triassic basins in the Netherlands and surrounding areas. PhD thesis Utrecht University (Utrecht), 171.

Geluk, M.C., 2007. Permian. In: Wong, T.E., Batjes, D.A.J. \& De Jager, J. (eds): Geology of the Netherlands. Royal Netherlands Academy of Arts and Sciences (KNAW) (Amsterdam): 63-84.

Geluk, M.C., Paar, W. \& Fokker, P., 2007. Salt. In: Wong, T.E., Batjes, D.A.J. \& De Jager, J. (eds): Geology of the Netherlands. Royal Netherlands Academy of Arts and Sciences (KNAW) (Amsterdam): 283-294.

Gussow, W.C., 1968. Salt diapirism: importance of temperature, and energy source of emplacement. In: Memoir of the American Association of Petroleum Geologists 8: 16-52.

Hansen, M.B., Scheck-Wenderoth, M., Hübscher, C., Lykke-Andersen, H., Dehghani, A., Hell., B. \& Gajewski, D., 2007. Basin evolution of the northern part of the Northeast German Basin - Insights from a 3D structural model. Tectonophysics 437: 1-16.

Jackson, M.P.A. \& Talbot, C.J., 1991. Glossary of salt tectonics. Geological Circular 91-4, Bureau of Economic Geology. University of Texas at Austin, 44.

Jackson, M.P.A. \& Vendeville, B.C., 1994. Regional extension as a geological trigger for diapirism. Geological Society of America Bulletin 106: 57-73.

Kombrink, H., Doornenbal, J.C., Duin, E.J.T., Den Dulk, M., Van Gessel, S.F., Ten Veen, J.H. \& Witmans, N., 2012. New insights into the geological structure of the Netherlands; results of a detailed mapping project. Netherlands Journal of Geosciences 91-4: 419-446, this issue.

Mohr, M., Kukla, P.A., Urai, J.L. \& Bresser, G., 2005. Multiphase salt tectonic evolution in NW Germany: seismic interpretation and retro-deformation. International Journal of Earth Sciences 94: 917-940.

Nalpas, T., Le Douaran, S., Brun, J.P., Unternehr, P. \& Richert, J.P., 1995. Inversion of the Broad Fourteens Basin (offshore Netherlands), a small scale model investigation. Sedimentary Geology 95: 237-250.

Peryt, T.M., Geluk, M.C., Mathiesen, A., Paul, J. \& Smith, K., 2010. Zechstein. In: Doornenbal, J.C. \& Stevenson, A.G. (eds): Petroleum Geological Atlas of the Southern Permian Basin Area. EAGE Publications b.v. (Houten): 123-147.

Racero-Baena, A. \& Drake, S.J., 1996. Structural style and reservoir development in the West Netherlands oil province. In: Rondeel, H.E., Batjes, D.A.J. \& Nieuwenhuijs, W.H. (eds): Geology of gas and oil under the Netherlands. Kluwer Academic Publishers (Dordrecht): 211-228.

Remmelts, G., 1995. Fault-related salt tectonics in the southern North Sea, the Netherlands. In: Jackson, M.P.A., Roberts, D.G. \& Snelson, S. (eds): Salt Tectonics: a Global Perspective. American Association of Petroleum Geologists Memoir: 261-272.

Remmelts, G., 1996. Salt tectonics in the southern North Sea, the Netherlands. In: Rondeel, H.E., Batjes, D.A.J. \& Nieuwenhuijs, W.H. (eds): Geology of gas and oil under the Netherlands. Kluwer Academic Publishers (Dordrecht): 143-158.

Scheck, M., Bayer, U. \& Lewerenz, B., 2003a. Salt redistribution during extension and inversion inferred from 3D backstripping. Tectonophysics 373: 55-73. 
Scheck, M., Bayer, U. \& Lewrenz, B., 2003b. Salt movements in the Northeast German Basin and its relation to major post-Permian tectonic phases - results from 3D structural modelling, backstripping and reflection seismic data. Tectonophysics 361: 277-299.

Schroot, B.M. \& De Haan, H.B., 2003. An improved regional structural model of the Upper Carboniferous of the Cleaver Bank High based on 3D seismic interpretation. In: Nieuwland, D.A. (ed.): New Insights into Structural Interpretation and Modelling. Geological Society Special Publications 212 (London): 23-37.

Stewart, S.A., 2007. Salt tectonics in the North Sea Basin: a structural style template for seismic interpreters. In: Ries, A.C., Butler, R.W.H. \& Graham, R.H. (eds): Deformation of the Continental Crust: The Legacy of Mike Coward. Geological Society Special Publication 272 (London): 361-396.

Stewart, S.A., Harvey, M.J., Otto, S.C. \& Weston, P.J., 1996. Influence of salt on fault geometry: examples from the UK salt basin. In: Alsop, G.I., Blundell, D.J. \& Davison, I. (eds): Salt Tectonics. The Geological Society (London): 175-202.

Taylor, J.C.M., 1998. Upper Permian - Zechstein. In: Glennie, K.W. (ed.): Petroleum Geology of the North Sea: Basic Concepts and Recent Advances. Blackwell (0xford): 174-212.

Trusheim, F., 1960. Mechanism of Salt Migration in Northern Germany. American Association of Petroleum Geologists Bulletin 44: 1519-1540.

Urai, J.L., Schléder, Z., Spiers, C.J. \& Kukla, P.A., 2008. Flow and transport properties of salt rocks. In: Littke, R., Bayer, U., Gajewski, D. \& Nelskamp, S. (eds): Dynamics of Complex Intracontinental Basins: The Central European Basin System. Springer-Verlag (Berlin, Heidelberg): 277-290.

Van Adrichem Boogaert, H.A. \& Kouwe, W.F.P., 1993. Stratigraphic nomenclature of the Netherlands, revision and update by RGD and NOGEPA, Section A, General. Mededelingen Rijks Geologische Dienst 50: 1-40.

Van Buggenum, J.M. \& Den Hartog Jager, D.G., 2007. Silesian. In: Wong, T.E., Batjes, D.A.J. \& De Jager, J. (eds): Geology of the Netherlands. Royal Netherlands Academy of Arts and Sciences (KNAW) (Amsterdam): 43-62.

Van Gent, H., Urai, J.L. \& Keijzer, M.D., 2011. The internal geometry of salt structures - A first look using 3D seismic data from the Zechstein of the Netherlands. Journal of Structural Geology 33: 292-311.

Vendeville, B.C., 2002. A new interpretation of Thrusheim's classic model on saltdiapir growth. Transactions Gulf Coast Association of Geological Societies 52: 943-952.

Vendeville, B.C. \& Cobbold, P.R., 1987. Glissements gravitaires synsedimentaires et failles normales listriques: mode les experimentaux. Comptes Rendues de l'Academie des Sciences, Paris 305: 1313-1319.

Vendeville, B.C. \& Jackson, M.P.A., 1992. The rise of diapirs during thin skinned extension. Marine and Petroleum Geology 9: 331-353.

Verweij, J.M., Souto Carneiro Echternach, M. \& Witmans, N., 2009. Terschelling Basin and southern Dutch Central Graben. Burial history, temperature, source rock maturity and hydrocarbon generation - Area 2A. TNO (Utrecht), Report number 034-UT-2009-02065.

Verweij, J.M. \& Witmans, N., 2009. Terschelling Basin and southern Dutch Central Graben Mapping and modeling - Area 2A. TNO Built Environment and Geosciences (Utrecht). Report number TN0-034-UT-2009-01569, 65. 